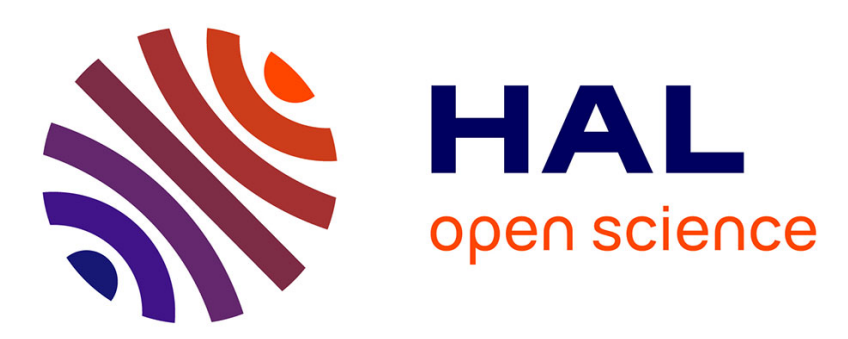

\title{
The Navy and the City. Conflict, cooperation and political competition in the urban governance of Toulon
}

\author{
Francesca Artioli
}

\section{To cite this version:}

Francesca Artioli. The Navy and the City. Conflict, cooperation and political competition in the urban governance of Toulon. Urban Research and Practice, 2013, 6 (1), pp.75-94. 10.1080/17535069.2012.762219 . halshs-01562520

\section{HAL Id: halshs-01562520 \\ https://shs.hal.science/halshs-01562520}

Submitted on 12 Dec 2017

HAL is a multi-disciplinary open access archive for the deposit and dissemination of scientific research documents, whether they are published or not. The documents may come from teaching and research institutions in France or abroad, or from public or private research centers.
L'archive ouverte pluridisciplinaire HAL, est destinée au dépôt et à la diffusion de documents scientifiques de niveau recherche, publiés ou non, émanant des établissements d'enseignement et de recherche français ou étrangers, des laboratoires publics ou privés. 
1 Published as:

2 Francesca Artioli. 2013, The Navy and the City. Conflict, cooperation and 3 political competition in the urban governance of Toulon. Urban Research and 4 Practice, 6(1), pp.75-94.

5

6

7

8

9

\section{Francesca ARTIOLI \\ The Navy and the City. Conflict, cooperation and political competition in the urban governance of Toulon.}

\section{Abstract}

This article contributes to the debate about urban governance in specialised European cities, by focusing on the interplay between changes in national defence policies and local initiatives. The paper is based upon qualitative research carried out in Toulon, a mid-sized French city and the biggest military port on the Mediterranean Sea. Firstly, it explains how the emergence of a new urban agenda aimed at diversifying the city from its military function challenged existing relations between the city and the Navy. As a consequence, new areas of conflict and cooperation can be observed. Secondly, it shows how political strategies adopted by elected officials respond to the need to legitimise the new agenda and to constrain the Navy to participate in it, while managing the military constituency. Despite a political discourse that proclaimed convergence of interest between the city and the Navy, the existence of a major conflict concerning the use and control of space doomed the partnership to a (partial) failure.

Keywords: urban governance, political competition, policy failure, defence policies, Toulon, Navy 


\section{Introduction}

Current literature on European cities underlines that a proper understanding of the dynamics of urban change needs to address not only the effects of economic change (the various forms of spatial restructuring of capitalism) or interactions between local organized groups and the political sphere, but also the effects of central government activities and national policies, which play an essential role in steering urbanisation processes and leading economic development (Le Galès, 2003; Haussermann, Haila, 2004; Giersig, 2008).

In a period of reorganisation of nation States, refocusing attention on changes in national policies offers interesting insights on the ways resources and power are redistributed among different level of governments, and on the consequences these changes have for cities (considered as localised societies and political systems). The existing literature deals with the urban consequences of welfare state reforms (Kazepov, 2005, 2010), and of metropolitan development policies (Béhar, Estèbe 1999; Brenner, 2003), but there is a significant lack of research on central government prerogatives and policies, namely defence policies.

This article contributes to the debate about urban governance and the mechanisms for urban change. It focuses on the interplay between, on the one hand, transformations in national defence policies and their effects at the urban level, and on the other hand, local initiatives and political regulation. History shows that the fabric of European cities has been influenced by the creation of military infrastructures, and that defence strategies have contributed to the shaping of the geography of urban growth and decline (Hohenberg, Lees, 1995). In European countries defence expenditure is still between $1.5 \%$ and $2.5 \%$ of GDP (SIPRI Military Expenditure Database, 2010, for Europe 15), Ministries of Defence remain among the biggest administrative bodies, and are the foremost owners of public real estate. However, since the end of the Cold War, defence policies in European countries have been changing, in terms of both their goals and how they are organised. After the high spending of 
the 1980s, expenditures shrank in the 1990s and then stabilised in the 2000s (with national differences corresponding to the degree of participation in the Afghanistan and Iraqi wars). Intervention outside national territories became the main task for professionalised military organisations. Furthermore, the geography of defence policies has changed. At the national level, spatial reorganisation of armed forces within the national space entailed the restructuring and/or the closedown of several military sites. This is particularly true for countries in continental Europe, whose military geography was previously determined by the East-West confrontation. These transformations can also be considered in terms of their effects on local communities. National policies and government spending in all its various forms (wages, pensions, military procurement, infrastructures, etc.) contribute to the structuring of local economies and societies over time. Changes in the institutional resources and economic weight of the military administration therefore have consequences in those urban settings where these influence how the local society is organised.

This paper presents the case study of Toulon, the biggest military port on the Mediterranean Sea, a mid-sized European city with around 170,000 inhabitants located in the touristic French Riviera, and the central municipality of a metropolitan area of 400,000 inhabitants. Toulon was chosen for this case study because of the military specialisation of the city. Indeed, the Navy has made a contribution to the structuring of urban development over time, and is a relevant urban institutional actor in terms of employment, landholding and political sway. The theoretical framework developed to analyse urban policies in Toulon conceptualises this city as a specialised European city. Urban studies have investigated specialised cities, mostly industrial cities and port-cities. Here, new forms of partnership between local governments and economic interests have developed in response to economic and political change (Section 1). Drawing on this research and their results, this paper focuses on urban policies in Toulon, in order to analyse the interplay between State restructuring and 
urban governance and to provide insights on local political responses to changes in nation State policies. The way the empirical object is constructed therefore makes Toulon a relevant case study for two complementary dimensions of urban change: 1 . Toulon as a military city in times of State restructuring, and where changing relations between local governments and the military administration can be observed; 2. Toulon as a specialized specialised European city, whose mechanisms of change are compared to those observed in other specialised cities (cityports and one-company towns).

The analysis of the evolution of the relationship between the Navy and the local government allows explaining a pivotal period for urban change in Toulon. Two empirical results are pointed out. The first is that the shrinkage of the contribution of defence activities to the local development, along with the consolidation of national policies of decentralisation and for metropolitan development, opened a window of opportunity for a new policy agenda. The Mayor elected in 2001 promoted an urban agenda aimed at greatly increasing the diversification of the city from its military function. This represented a challenge to existing relations between the Navy and the city, and created new areas of conflict and cooperation between urban elites. The second result is that, in order to understand the political strategies designed both to legitimise and to constrain the mobilisation of the Navy in a local development project, two factors must be taken into account: on the one hand, the material and political resources available to the relevant actors; and on the other hand, the need for elected officials to avoid alienating the military constituency and the consequent electoral sanctions that this might have. Despite a political discourse that proclaimed convergence of interest between the city and the Navy, the existence of a major conflict concerning the use and control of space doomed the partnership to a (partial) failure. 


\section{Urban change in specialised cities: theoretical perspectives for the study of Toulon}

In the example this article studies, the Navy is an actor with authority and management over significant resources in the city, external to urban government. Resources are defined here as all those elements which can be used by actors in the policy process (Hassenteufel, 2008: 105). In this sense, resources are both material (expenditure and investment capacity, land, organisational capacity, and know-how) and political (representativeness and legitimacy). Interests and resources evolve in time, and both contribute to shape the strategies of the actors in the policy process (Hassenteufel, 2008: 105). In pursuing an understanding of urban policies in the city, reference needs to be made to theories that address two central questions. Firstly, there is the relevance here of those theories which address the issue of relations between urban governments and those actors who control relevant resources in cities, and more precisely the theories that focus on cities specialised in certain activities. The second field of research is the one that explores how relations among actors have been changing during recent decades in European urban policies. This twofold approach provides an explanation both as to how urban governance is conceptualised in the present case study and also how the case of Toulon, a mid-sized military city, fits within existing research on European cities and can be compared to its results.

\section{a. Who governs in specialised cities?}

One of the main contributions classical middle-range theories of urban policies - regime theory (Stone, 1989) and urban growth coalitions (Logan, Molotch, 1987) - brought to the discipline was to underline that urban policies have to be understood beyond local government action. Because these theories originated in the U.S.A., their applicability to European cases is strongly debatable (Harding, 1991; Stoker, Mossberger, 1994; Le Galès, 1995), mostly because they incorporate assumptions about the role of the state and the market in urban policies. Indeed, they do not fit the political economy nor the institutional design of 
cities in Europe, where the state and the public sector in general have played a greater and more sustained role in the organisation of urban societies. However, these theories orientated urban research toward the study of coalitions between local governments and those actors who occupy a strategic place in the definition of policy priorities, precisely because of their control of relevant resources. From a different perspective, the European sociological tradition analyses city governments and social regulation processes in cities which are specialised in certain activities (one-company towns, city-ports, etc.). Instead of "who governs?" the main question here concerns how social and political orders are constructed and maintained in "localised societies" (Bagnasco, 1986), where a particular kind of activity or economic organisation is dominant in the economic sphere (Pizzorno, 1960; Bagnasco, 1986). The starting point for this kind of research is to assess how specific and localised activities contribute to the structuring of the social organisation of the city. Thereafter, they focus on how the State, the market and relations of cooperation/reciprocity interplay in producing and sustaining a localised social organisation. In other words, they focus on regulation, which is defined as the existence of a relatively stabilised system of coordination of different activities, resource allocation and conflict solving between actors (Lange, Regini, 1989). A prominent example is the study made by Arnaldo Bagnasco of the city of Turin in the 1980s, focused on FIAT, the automotive company which has had a leading role in local development since the beginning of the 20th century. Bagnasco established a "sociological profile" of the city, starting from the understanding of how the organisation of FIAT contributed to the structuring of other forms of organisation, and how it continued to interplay with them not only in the sphere of industrial production but throughout the whole of urban society. The contribution brought by this kind of literature to the present case study is to place the local policy process within that of production and reproduction of localised society. 


\section{b. What has been changing? National policies and local governance in Europe}

Studies of the evolution of European city governments since the 1970s provide some elements for understanding how macro-processes contributed to modifying the shaping of urban policy-making, and transformed opportunities and constraints for urban governments. Firstly, economic change has intensified pressures on municipalities. Large companies and public sector organisations that used to provide stable employment in many localities have been restructured, and this, together with the shrinking of traditional industries and the increased mobility of capital and labour, has put cities in competition with each other in trying to attract promoters and providers of production (Scott 2008). Secondly, changes in national policies contributed to modifying policy-making. Devolution and decentralisation processes increased responsibilities of local government institutions for the definition and implementation of public policies (Bobbio 2002). Furthermore, the way state policies address the problems of local development has changed. Until the 1970s national policies focused on redistributive issues and on the direct sustaining of economic development. Along with the reduction in State resources and the limitation on economic interventionism introduced by European Union, national territorial policies became competitive-based in the allocation of resources. They also became oriented towards promoting the mobilisation of local actors (Brenner, 2004; Béhar, Estèbe, 1999; Pinson, 2009 for the French case). This has reinforced competition among local governments in their struggle to attract resources from the national State (Jessop, 1993; Brenner, Theodore, 2002; Brenner, 2004), and opened up political opportunities for local leaders (Le Galès, 2003).

If attention is shifted from macro-processes to urban policies, empirical research shows patterns of convergence in how European cities are governed, understood as how decisions are taken in urban policies, and who participates in local policy-making. The main change is the emergence of new forms of partnership between actors controlling relevant resources in 
cities and cooperating for locally elaborated development projects. John observes, "even though institutions (local government) do not vanish, institutionalised forms of local politics have given way to more flexible and networked patterns of public decision-making" (John, 2001: 22-23). This has been defined as a shift from urban government to urban governance (Le Galès, 1995). Urban governance is understood here as the process of coordinating actors, social groups, and institutions to attain particular goals, which are discussed and defined collectively in fragmented and uncertain environments (Le Galès, 1995). In this context, Mayors have to play a relevant role in aggregating interests, mobilising actors who control resources for local policy-making (private companies, universities, local elites), and solving conflicts. In turn, this can increase mayoral political authority and recognition (John, Cole, 1999; Borraz, John, 2004). More precisely, several pieces of research demonstrate that in French metropolitan areas there has been a reinforcement of political entrepreneurship on the part of mayors since the beginning of decentralisation in 1982 (Lorrain, 1991; Prat, 2008).

The discussed changes take a particular form in cities which are specialised in some activities. Indeed, similar strategies of elected authorities in building coalition for local policies have been observed. Here, resource concentration is critical. Urban agendas in specialized cities have required the implication of those actors under whose control are concentrated material, financial and political resources (Pinson, 2009). Going back to the example of Turin (i.e. a one-company town), when the mayor elected in 2001 launched a new agenda for reinforcing the "new economy" in the city, the company FIAT was targeted as the major partner of the project. FIAT's participation was necessary both because of the resources (employment, land, financial) controlled by the company, and because the participation of the top management of the company brought an increased legitimacy to the urban agenda (Chiamparino, 2002). 
This case study of Toulon combines the approaches from the literature that discusses urban policies in specialised cities with the literature about urban governance in European cities. This investigation of the policy process therefore integrates, on the one hand, analysis of the effects of the military specialisation on local society, and on the other hand, analysis of how relations between the Navy and the local government evolved in the context of changes in resources available to them. For our purposes, urban governance - i.e. a specific form of coordination for collective action - is an "empirical phenomenon" (Pierre, 2005: 453), meaning that the observer must search for processes through which significant and resourcefull actors coordinate their actions in the pursuit of collectively defined objectives (Pierre 2005). Empirical research has established that there are two kinds of interrelated processes which sustain the mobilisation of the resources of relevant actors (John, Cole, 1999; Pierre, 2005; Dormois, 2008; Pinson 2009). The first is the emergence of flexible local institutions where decisions can be negotiated, which leads to the densification of information exchange networks and long-term greater institutional capacities. The second is the recognition of shared interests between actors, and the consolidation of a common framing of policy problems (Stoker, Mossberger, 1994; DiGaetano, Strom, 2003; Kilburn, 2004; Pierre, 2005). Coordination for collective action is therefore considered as a possible outcome, rather than as a necessary outcome resulting directly from macro-transformations. In fact, in interorganisational negotiation processes, gridlocks and interruptions are frequent (Stoker, 2011). Further, the locally-specific distribution of resources (material and political resources) among actors helps explain why certain policies are formulated in particular ways, and why some possible outcomes are systematically left aside. For these reasons, the study analyses local policy-making from the perspectives of resources available to the Navy and the local government, and of relations between them. Two questions oriented the research: 1 . How did 
material and political resources available to the Navy and the local government evolve over time? 2. To what extent do local actors cooperate, and through which processes collective action is built up (common framing of policy problems, institution building)?

Drawing on the literature discussed above, two main hypotheses gave origin to the fieldwork and were empirically tested. The first hypothesis concerns change in relations between local government and the Navy, one of the most powerful actors in the city. Since devolution and new national policies for territorial development provide incentives for the emergence of local projects which imply the mobilisation of local relevant actors, new forms of cooperation between urban elites were to be expected. This would make urban policies in Toulon similar to those observed in other specialised European cities. The second hypothesis relates to strategies of elected officials in the process. Since the Navy is as much a group of inhabitants and voters as an institutional actor, it was expected that any loss or potential loss this group suffered due to policy framing and implementation would have been likely to evoke a response that followed a logic of blame avoidance.

Empirical results are developed in the three following sections. Section 2 defines how the economy, the urban space and the political competition in Toulon have been influenced by the military presence. Section 3 shows how a new urban agenda has emerged since 2001, and explains how it challenged existing relations with the Navy. Finally, section 4 deals with policy definition and implementation, and it analyses both how policy problems are formulated by politicians, and relations between the City and the Navy in the implementation process.

Data for this study were collected from 30 semi-structured interviews with Toulon elected officials and civil servants (in the departments for planning, economic development and general affairs), and with acting and retired military commanders. The main regional daily newspaper (Var Matin, circulation 71,235), the official report of the municipality, published 
once a month and distributed to all the households in the city and in the main public buildings), and relevant city documents concerning urban public policies (collected during the interviews and in the municipal archives) were analysed. Data on Toulon's inhabitants who had a connection with the Ministry of Defence (MoD) were obtained from the Ministry itself and from the administration of Toulon. The fieldwork aimed at tracing the evolution of relationships between the actors of interest in the policy process, and at unfolding how they framed their interests and resources. Interviews with retired civil servants, elected officials and high ranked marines were particularly useful for the understanding how changes occurred since the 1990s.

\section{The Navy as a public administration and as a group of voters}

\section{a. Toulon: the foremost military Mediterranean port or a touristic spot on the French}

\section{Riviera?}

Toulon is the foremost military port on the Mediterranean Sea, and currently $70 \%$ of the French fleet of warships is based there, including France's only nuclear aircraft carrier. The military presence influenced urban development in three relevant and inter-related issues: political autonomy; economic development; and urban layout.

The first one is political. In the 17th century, the French monarchy established the military dockyard in Toulon and, since then, urban development has followed the ups and downs of national defence strategies and policies. Since the Navy is a hierarchical organisation whose headquarters are located in Paris, decisions concerning local issues were taken at the national level. The second issue is related to urban economy and employment (Table 1). For centuries, the Navy has been the primary employer in the area, mostly because of activities related to warship construction and maintenance. In the 1950s, half of the masculine population in work was employed in this sector (Agulhon, 2000). From the end of the 1980s, public expenditure 
in both naval and military sectors shrank ${ }^{1}$. Even though the military port of Toulon continued to be extremely relevant for national defence (because of the increasing strategic relevance of the Mediterranean frontiers of Europe), employment in the military dockyard decreased. The number of workers in the warship construction shrank from more than 7,000 in 1984 , to around 5,000 in 1994, then to 3,000 in $1998^{2}$ and to 2,000 today ${ }^{3}$. These changes contributed to rising unemployment rates in the $1990 \mathrm{~s}^{4}$ (in Toulon $20 \%$ of the active population was unemployed in 1999), to the failure of military subcontracting firms, and to negative net migration rates (Toulon population decreased by 7\% between 1982 and 1990, by $4 \%$ between 1990 and 1999, and then stabilised in the following decade) $)^{5}$. Ministry of Defence provides 17,177 direct jobs out of a total of 75,931 jobs (22.6\%). Toulon had 167,816 inhabitants in 2006 , of whom 70,764 were in work, and 8,310 worked for the Ministry of Defence, which means that $11.7 \%$ of residents in work were employed by the military administration. Moreover, 8,053 people in Toulon receive a military pension, which is a significant share of $20.7 \%$ of the retired inhabitants in the city $(75,931)$. However, the city of Toulon is also located in one of most attractive regions for tourism ${ }^{6}$, and in recent decades the metropolitan area has become a favoured destination for wealthy retired people, who

\footnotetext{
${ }^{1}$ At the national level, defence expenditures represented 3.6\% of the GDP in 1988 (EU 15 mean was 2.7\%), $2.7 \%$ in 1998 (EU 15 was 1.9\%), 2.3\% in 2008 (EU 15 was 1.7\%). Source: SIPRI Military Expenditure Database ${ }^{2}$ Sources: Hebert (1995) and Préfecture Maritime de la Méditerranée.

${ }^{3}$ In 2003 the military dockyard company DCN became a publicly owned company governed by private law, and in 2007 its capital was opened to private investors.

${ }^{4}$ In the context of French economic recession of the late 1980s and early 1990s an additional event which had negative effects for Toulon was the closedown, in 1986, of the civil dockyards located in the neighbouring municipality of La Seyne. 4,191 people used to work there. Source: Tixidor, Manuel; Martins Dias, Raphaël; Daviet, Sylvie (éd.) (2010). Les difficultés de la reconversion à La Ciotat et à La Seyne-sur-Mer. Rives méditerranéennes. (Industrie-Ville-Territoire en Provence), (4), p. 35-45.

${ }^{5}$ During the last 30 years the population decreased in the city of Toulon and in the industrial city of La Seyne, but increased in the surrounding area (between 1982 and 2006 the agglomeration Toulon Provence Méditerranée as a whole gained 35,281 inhabitants, $+7.8 \%$ ). Source: INSEE.

${ }^{6}$ In 2009, the PACA region ranked second (after Paris) for annual overnight stays. The Department of Var (one of six Departments of PACA region) has $30 \%$ of regional overnight stays. Source: Direction générale de la compétitivité, de l'industrie et des services (Ministère de l'Economie).
} 
move there from other French regions ${ }^{7}$. Despite their relevance in the metropolitan economy, military activities are not the most dynamic sector in terms of job creation ${ }^{8}$. In fact, the leading economic sectors are those related to consumption, real estate and care services. In the metropolitan area, the four sectors where the most jobs have been created between 2000 and 2006 were social services $(+1,571$ jobs), food and beverage service activities $(+1,145)$, retail trade $(+1,053)$, and real estate and related services $(+833)$ (Davezies, 2008b). Compared to neighbouring municipalities in the metropolitan area, Toulon's touristic activities are underdeveloped, both in terms of touristic flows and share of secondary residences ${ }^{9}$. This dynamics of the metropolitan area is at the heart of Toulon urban policies. military and civilians ports and within the narrow space between the hills and the sea, which constrained urban extension. The constructible parts of the city have been completely urbanised in four decades. Today, new real-estate developments are possible only through projects of urban renewal which replace the existing built environment. The Ministry of

\footnotetext{
${ }^{7}$ For Toulon metropolitan area: $15.8 \%$ of people who moved into the area between 1990 and 1999 were retired, which is a share similar to the Nice urban area (15\%), and more than four times the share of "retired newcomers" in Rennes urban area (3.1\%). The following decade had a similar trend (Davezies, 2008b).

${ }^{8}$ The general trend since the beginning of the 1980s has been analysed by the economist Laurent Davezies (2008a) in his research into the redistribution of revenue among French regions. The city of Toulon is located in an area whose revenue has been increasing thanks to the "residential economy" led by the influx of retired people and tourists.

${ }^{9}$ The metropolitan area had a hosting capacity of 20,849 beds for tourists, but the share of the city of Toulon is very small (5\%) compared to the neighbouring municipalities of Hyères (55\%), Le Pradet (13\%), and Six-Foursles-Plages (12\%). Similarly, in the city of Toulon the share of secondary residences on total housing is $2.9 \%$, far below the share of Hyeres (23.5\%) or Six-fours-les-Plages (30\%), and below the average of the department of Var (26.5\%). Sources: Toulon Provence Méditerranée, Direction générale de la compétitivité, de l'industrie et des services, Ministère de l'Economie, INSEE.
} 
under its control, which has been quite stable over time: today around 350 hectares ( $8 \%$ of the total area of the municipality) are owned or legally controlled by the $\mathrm{MoD}$, and 8 kilometres of the shore (mostly in the historical city centre) are dedicated to military activities, and closed to inhabitants and tourists. As a consequence, the plots of land the MoD owns, whose location in the city would make them an easy investment for the creation of a surplus value related to touristic developments, are not part of the land market. Secondly, there are laws securing public control of State land property against ownership by other interests that could be deemed to threaten their public functioning and use. A fortiori, the MoD can claim national interest and military confidentiality. Beside land ownership, some parts of the city are subject to building restrictions defined by the MoD, because of the technological and environmental risks related to military activities. Finally, maritime shipping in the bay is submitted to rules defined by the Préfet Maritime, the highest military authority in charge of the Mediterranean Sea, and whose office is located in Toulon.

Shares of urban spaces and bay waters under military control are regulated (organised and steered) according to a hierarchical organisation model, leaving local governments or other relevant groups or organisations with little capacity for action. This contrasts with the general course of urbanisation which has taken place in the Toulon metropolitan area under the pressure of demographic growth of the post-war development ${ }^{10}$. In fact, after WWII the city developed in a way that was broadly speaking unregulated because of speculative initiatives of private developers. In addition, since the 1970s the French Riviera has become a coastline which attracts tourists on a world-wide scale, and a profitable market of secondary residences has developed in the metropolitan area. In the coastline of the PACA region, the land market

\footnotetext{
${ }^{10}$ Around $40 \%$ of Toulon built environment was destroyed during WWII. The reconstruction and the post war economic boom was accompanied by a massive but weakly regulated urbanisation process (46.2\% of existing buildings were constructed between 1949 and 1974). Source: INSEE.
} 
is constantly under pressure and the Toulon urban area ranks third in France for the highest prices for land for construction ${ }^{11}$.

To conclude, the military administration in Toulon is a local powerful actor whose transformations depend on decisions taken in Paris, an institution ensuring an economic function thanks to military public expenditure, and a landowner having an influence on urban spatial fix which limited alternative developments. The idea of dependence is deeply rooted in the perceptions of Toulon city officials and is the cognitive framework within which the new agenda for urban development is embedded (Section 3).

\section{$\underline{\text { Map } 1}$}

\section{b. Soldiers and war veterans in the political competition in Toulon}

Toulon has been governed by right-wing parties since the end of WWII. Indeed, Mayor Maurice Arreckx ruled the city between 1959 and 1985, followed by his former vice-Mayor François Trucy (1985-1995). In the metropolitan area the far-right party Front National (National Front) has achieved significant electoral scores since the 1980s, and ruled the city between 1995 and 2001, when a new right-wing Mayor was elected. Because of their number, people living in Toulon who work or used to work for the MoD are a relevant part of the urban electorate. The perception of this constituency and of its political preferences contributes to shape what politicians offer during electoral campaigns, but also influences choices in public policies, how these are decided, implemented and publicly legitimized (Section 4). Following Weaver (1986), patterns of behavior of elected officials can be understood taking into account their interests in claiming credit with constituents and clientele groups for actions taken for their benefit, and in avoiding the blame for perceived or real

\footnotetext{
${ }^{11}$ Toulon urban area ranks third after Montpellier and Paris. Building land is 230 Euros $/ \mathrm{m} 2$, the average for the 100 more expansive urban area is 105 Euros/m2. Source: SOeS, enquête sur le prix des terrains à bâtir, Ministère du Développement Durable, de l'Ecologie et de l'Energie, 2008.
} 
losses imposed to some groups and constituencies. Two empirical results are relevant for the understanding of electoral stakes related to the Navy and the resultant consequences on the policy process. The first point is the very existence of a "military world"12 in Toulon, understood by elected officials as a distinctive group who contributes to structure political competition $^{13}$. Inhabitants related to defence activities are highly differentiated by age, revenue and mobility, and therefore in their needs for local public policies (e.g. housing, childcare, and care for elderly, etc.). However, in interview, local elected officials, both in the ruling right majority and the left opposition, identify a local electorate related to the military presence. When talking about political competition, interviewed politicians tend to consider career soldiers, volunteer soldiers, veterans, and their families as being part of this same and "extremely important" group. The second point is that this "military world" is considered to occupy a specific space in Toulon localised polity. Indeed, interviewed politicians shared a vision of the population related to defence activities as a right-wing oriented electorate.

Reliable statistical inferences about electoral choices of the military world cannot be made. In fact, there are no national surveys dealing specifically with the political orientation of members of the armed forces ${ }^{14}$. At the municipal level, home addresses of MoD employees are not available, which makes it impossible to cross-reference residential data with election results by polling station ${ }^{15}$. Nevertheless, in a city which has been right-wing oriented since the 1950s, there is a consensus among elected officials that the military world is a

\footnotetext{
12 The term "military world" is a label used by the deputy-mayor in charge of war veterans. The term includes the "monde combatant" (war veterans associations), but also career soldiers, volunteers, veterans, and their families. In general, all interviewed elected officials shared this vision of the existence of a specific electorate related to defence activities.

${ }^{13}$ Interviewed elected officials were: the deputy mayors (right-wing) currently in charge of urban planning and of war veterans; the deputy-major in charge of relations with the Navy (in charge between 2001 and 2008); the principal deputy-major, also Member of Parliament (right-wing); the Senator who was City Mayor between 1985 and 1995 (right-wing); the vice-president of the PACA Region (until 2010), who is also a member of the leftwing group in the City Council; and a former member of the left-wing opposition in the City Council (until 2008).

${ }^{14}$ National panels keep armed forces and police in the same professional category. These national samples therefore cannot be used for the purpose of this paper.
} 
constituency strongly supporting re-elections of ruling majorities rather than the left-wing oppositions. As the leader of the left opposition in the City Council commented, this is an electorate which every politician in Toulon has to "find a way to speak to, if he hopes to win local elections one day". One way to give symbolic recognition to this group in Toulon is to recruit well-known retired marines to participate to the electoral competition. In fact, the composition of electoral lists shows their social representativeness and their linkages with those groups who are considered as relevant constituencies (Lagroye et al., 2004). In the electoral lists of the last two municipal elections there were retired marines both in socialist and right wing lists, even if they were more numerous and higher ranked in the right wing list. Retired marines were recruited by leading candidates of both parties because of their professional affiliation, because "if we do not have these people on the list, a share of the population of the city is missing". Apart from the moment of electoral competition, maintaining support from this group and avoiding the blame influence politicians' motivations and activities. As soon as the current Mayor Hubert Falco was elected, he appointed three councillors to be in charge of dealing with "military affairs" and veterans, which was a quite significant number in view of the total number of councillors (22). More precisely, one of them was in charge of the 70 or so associations related to the "military word" registered in Toulon ${ }^{16}$, one responsible for ceremonies and official relations, and the third one (who was a well known retired admiral) dealt with policy-oriented relations with the Navy (Section 4b).

Although not completely homogenous, the "military world" is considered by local politicians as a relevant right-wing constituency in political competition. For the ruling right-

\footnotetext{
${ }^{15}$ The best way to understand how this group votes and how it is internally differentiated in its political preferences would be cross-referencing individual data with ecological data at the urban level.

${ }^{16} 66$ associations related to defence activities were found: 48 of them were war veterans' associations, 8 of them were of retired career officers, and 10 of them were support, cultural and sportive associations for armed forces members and their families. These associations are highly supported by the Municipality: they receive subsidies,
} 
wing Mayor, the political risk of electoral sanction is high. Discontent in military-related public opinion is therefore something to be avoided.

\section{How national policies and local political entrepreneurship challenged existing} relations with the Navy

\section{a. The emergence of an urban agenda targeting the Navy as a major partner}

In the context of the shrinkage of defence expenditure of the 1990s (Section 2.a), changes in national policies addressing urban and regional development and providing incentives for cooperation among actors open a window of opportunity (Kingdon, 1984) for the local government elected in 2001 to put forward a new policy agenda. The generally desired result is the diversification of the dependence of the city upon military (and military-related) activities in favour of enhancing touristic activities related to Toulon's location on the French Riviera. This is aimed at transforming Toulon into a "Mediterranean metropolis" 17 inspired by, and in competition with, the neighbouring city of Nice which succeeded in combining identity and functions of a well-established flagship touristic destination with the emergence of one of the biggest clusters for R\&D in France. The agenda in Toulon requires the mobilisation of resources held or controlled by the Navy.

Two main changes made possible the emergence of a new policy programme. Firstly, the Mayor elected in 2001 had greater political resources than the previous municipal administration. Maurice Arreckx was the city's right-wing Mayor for almost 30 years (19571985), and ruled a political system based upon corruption, sustained by the easy availability of public money (Ardid, 1995; Martin, 1996). During the 1990s, a moral, economic and political crisis hit the city, and several members of the economic and political elites were

a collective building with offices and common spaces, and dozens of ceremonies a year are celebrated in the city. Sources: Prefecture du Var and Toulon Municipally. 
swept away by lawsuits and scandals. After a highly contested far-right term of administration (1995-2001), the right-wing mayor Hubert Falco was elected. He became city mayor with a large majority, and benefited from a strong political legitimacy and central government support because he had defeated a far-right city council ${ }^{18}$. Moreover, like most current French mayors of big cities, he held posts in both central and local government. At the national level, he had held ministerial posts since 2002, the most recent being as Secrétaire d'État à la Défense et aux Anciens combattants (Secretary of State for Defence and for War Veterans). The city council and the Mayor elected in 2001 therefore had high local recognition and legitimacy, and a strong capacity to deal with the national government in order to defend local interests and to get resources from the centre.

Secondly, new national policies for territorial development designed to concentrate the allocation of public resources in key or leading places (Section 1) provided the Mayor with incentives and resources to elaborate an urban agenda for a "Mediterranean metropolis". This contrasts with previous ways of policy-making. Indeed, city civilian authorities describe the time from the end of WWII until the 1980s as a period where "we didn't need anything”, and nobody felt the necessity to develop city projects because both military public expenditure and the dockyards sustained local development without requiring any particular local mobilisation ${ }^{19}$. Since 2003 , the city has submitted three successful projects to the central government call for projects. The first project was based upon the cooperation in planning policies between institutions located in the same metropolitan area, as a way to override administrative boundaries and metropolitan fragmentation. The second, this time designed to

\footnotetext{
${ }^{17}$ The «Mediterranean metropolis » definition is used in the municipal magazine Toulon Méditerannée Magazine in all the articles about strategies for urban development.

${ }^{18}$ During the far-right term municipal government was isolated, almost ignored, by the central government, as reported by both one of the Prefects of Toulon and by the Ministry of Defence of that time (both have been interviewed).

${ }^{19}$ Maurice Arreckx deputy-Mayor and the former City Manager (hired in the 1970s) were interviewed.
} 
promote the development of $\mathrm{R} \& \mathrm{D}$ clusters, involved enhancing the collaboration between local government, research institutions and local firms. Both projects meant an inflow of

financial resources from the central government specifically limited to the elaboration of policies that required partnership with relevant institutional and economic actors at the local level. The third project, related to decentralisation, transferred ownership and management of the civilian port to local authorities. This meant that the local government in Toulon acquired greater power in setting the shipping rules in the bay, power which was formerly shared by the Ministry of Defence and by the Ministry of Transport.

All these initiatives put forward a new encompassing vision for the city. The main idea is to "open the city to the sea", and to make Toulon exploit the potential of its position on the French Riviera, as neighbouring cities were doing. This would be done through: the development of touristic activities on the city marina; the enhancement of maritime civilian transport; and the development of R\&D in marine and submarine fields. For elected officials, the Navy is the most relevant partner for a successful implementation of such an agenda. Indeed, transforming Toulon into the so-called "Mediterranean metropolis" implies the mobilisation of two kinds of resources locally associated with the Navy. Since the city does not have a relevant university, but rather all the most advanced research centres are related to the Navy, its research and development activities are considered as the main source for further developments in R\&D. Secondly, what is seen as decisive for the implementation of the agenda is the urban space (land and water) controlled by the Ministry of Defence.

\section{b. Conflicting interests about the use and control of urban space}

Both mutual interests and the nature of the resources targeted by Mayor Falco need to be taken into account for any understanding of conflict and cooperation between the city and the Navy. To some extent, the Navy participates in a local partnership in those realms which are clearly identified as of converging interests. The military administration and the local 
government office for economic development collaborate with firms in the marine and submarine sector, within the institutional and financial framework made possible by the national call for R\&D clusters. The military administration orientates local firms towards strategies which are more liable to correspond to the future needs of the armed forces.

Moreover, Toulon has become one of the key places chosen by the MoD to promote and make visible its new "policy of sustainability". The Navy is a partner in a project for the improvement of the poor quality of bay waters, which is part of the metropolitan project developed by all the municipalities around the bay, and led by Toulon's local government, in response to the national call.

However, the cooperation between military and political elites is hindered by conflicts about urban spaces. On the one hand, action over urban spaces is one of the most important and defining characteristics of city government. Through zoning, it provides the leverage which allows local authorities to influence which activities are located in the city. As such, it is an instrument that helps to regulate the benefits which different groups can derive from a specific pattern of activities (Harvey, 1985). In Toulon, the decentralisation of civilian port management has made the development of consumption-oriented activities one of the sought after evolutions for the city. Political elites put forward a project for the waterfront renewal which implies a shift from military to civilian use of a great part of the Eastern coast of the bay and a revision of the shipping rules in the bay. Inspired by some well-known urban experiences such as those of Genoa, Bilbao and Cardiff, and supposed to symbolise the "Mediterranean metropolis" this responds to a strategy of touristic development. Furthermore, given the lack of land for development in Toulon, the land owned by the military administration in the city centre (close to the port and to the military hospital) constitutes an opportunity for the acquisition of land by the city through political negotiations, and potentially at below market price. On the other hand, the first interest of the Navy in Toulon is 
to maintain and ensure the conditions necessary to its own functioning. Given that land use,

493

494

495

496

497

property disposal and spatially defined security rules are the material means for the military institution to function, the necessity of maintaining some control over those elements is a permanent goal of the military administration. Moreover, the Navy considers Toulon its key military port in France, whose strategic relevance is going to increase (rather than decrease, as it is the case for some ports on the Atlantic Ocean) as a consequence of the concentration of geopolitical crises in the Mediterranean area. Enhancement of military activities in Toulon with the building up of new infrastructures is planned for the years to come.

The emergence of a new agenda aimed at "opening the city to the sea" therefore led to the emergence of diverging interests about the use and control of urban space, and challenged existing relations. Interviewed about this issue, city officials and military commanders who have been in post in recent years described a power struggle in the making ${ }^{20}$. When the land is at stake, the ideas of "standing firm," "sticking to our guns" and "showing who really rules the city" are more than frequent. However, both the direct ownership and the authority to set the rules over significant shares of land and waters (Section 2) make the Navy an institutional veto player for changes in the use of urban space. A veto player is an actor whose agreement is required for a change of the status quo (Tsebelis, 2000). In other terms, local projects for urban renewal need the approval and/or the cooperation of the military administration because of the location and the amount of urban space under military control.

\footnotetext{
${ }^{20}$ Interviewed military commanders were: the deputy commanding officer for the Mediterranean- CECMED (since 2008); the deputy commanding officer for the Mediterranean- CECMED (2005-2008); the responsible for external communication of the CECMED; the retired admiral in charge of relations with the Navy in the local government (2001-2008); the deputy commanding officer for the Mediterranean-CECMED (1991-1996); the commanding officer of the service for military infrastructures; the commanding officer of the service for military housing; the deputy commanding officer for the Mediterranean, later in charge of relations with the Navy in the metropolitan agglomeration.
} 


\section{Political strategies for implementing policy-making and avoiding blame}

The investigation of urban governance as an empirical phenomenon requires focusing on relations among actors in the policy process. Since the early 2000s, the newly-elected Mayor adopted several strategies to establish cooperation with the Navy and to mobilise its resources. These strategies are the results of trade-offs between electoral motivations - i.e., managing electoral risks related to the particular sociology of the city - and wanting to implement public policies. The institutionalisation of bi-lateral meetings, the use of political resources to reach the central government, and a political construction of losses and gains framing policy problems are the main strategies developed for the management of the relations between the city and the Navy.

a. Issue framing, causal stories and blame avoidance: the political construction of losses and gains

Since 2001, elected authorities of Toulon have developed a new public framing of the military presence, which was absent during previous mandates ${ }^{21}$. This framing is part of the political communication, and is publicised in the monthly municipal newspaper distributed to all households (Toulon Méditerranée Magazine) and in the interviews released by elected officials to the regional newspaper, Var Matin. The framing of the military presence challenges the distribution of material resources in the city, as well as the prominent role of the Navy in urban development, while pursuing strategies of avoiding blame (Weaver, 1986) from the military constituency. Indeed, strategies for managing the military electorate are

\footnotetext{
${ }^{21}$ The analysis of the policy framing is based upon three main sources: the reading of the monthly municipal newspaper since the beginning of the 1990s, and more precisely the comparison between the Front National term (1995-2001) and the right-wing terms (since 2001); the analysis of official documents for urban planning and economic development; interviews with local elected officials and civil servants, active and retired. For the list of interviewed elected officials see footnote $n^{\circ} 12$. Interviewed civil servants were: the City General Manager (since 2008), the former City General Manager (who became in 2008 the new Port Authority Manager), the manager of Housing Service (formerly manager of Urban Development Service), the project manager of the "Grand Projet Rade" (Communauté d'agglomération Toulon Provence Méditerranée), the General Manager of the Communauté d'agglomération Toulon Provence Méditerranée, a researcher in the Toulon Agency for Urban Planning (AUDAT).
} 
visible both in the political construction of losses and gains which are expected from the new agenda, and in the public discourse about the decree of consensus in the relations between the city and the Navy.

Issues framing is the process of "image making, where the images have to do

fundamentally with attributing cause, blame and responsibility (...). Conditions, difficulties or issues do not have inherent properties that make them more or less likely to be seen as issues to be dealt with through public policies" (Stone, 1989: 282). Rather, using narrative causal stories political actors deliberately portray them in ways calculated to gain support for their side. The construction of arguments establishing causal linkages between events is relevant not only because it places a problem on the policy agenda, but also because it provides an interpretation of the past and, by the same token, defines the range of possible ways of solving that problem in the future, and excludes alternative possible solutions. The analysis of the two main arguments about the Navy framing the new agenda reveals a strategic presentation of history. This is aimed at normalising the military presence in Toulon (i.e., making the Navy an urban actor among others) and mobilising the institution's resources for a future win-win situation, which will benefit both the city and the Navy. The first point focuses on the land issue. City officials in charge of urban development and planning put forward that historically , the military presence constrained the development of the city and its waterfront in the past. Then, it is claimed that armed forces have been restructuring, and that contemporary and highly technological armed forces no longer need such a large amount of property. In consequence, it is argued that the military administration could easily transfer some of it to the city and make it available for a "civilian-use reconversion". This historical narrative is accompanied by the claim that the city will never attempt to obtain a single "strategic square 
metre ${ }^{, 22}$ controlled by the Navy. The statement is understandable as a way of avoiding blame: it establishes that the city (the local interest) is never going to harm national defence interests. However, what is "strategic" is undefined, and therefore open to conflicting definitions and negotiations. The second point concerns the normalisation of some services and benefits in the city, historically provided by the military administration to its members in an exclusive manner. The idea of "sharing" ("partage” in French) recurs in all the interviews with city officials in post. It is justified by the claim that military activities are no longer the core of city economic development. Therefore, the institution should renounce some of its advantages in the city, both in terms of spaces and services (marines used to have their own shops, their own leisure clubs, and the MoD still rules a quasi-autonomous system for social housing). Marines are "Toulon citizens just like any others",23, and they have no reason not to share their benefits with all of Toulon's inhabitants. At the same time, is argued that policies of urban renewal and economic diversification are going to generate benefits for everybody, including MoD employees. Being city inhabitants and voters, they are expected to benefit from urban policies and future economic growth. To summarise, public framing of the new agenda starts from the idea that the Navy was an exogenous power having a strong influence on city development. Then, it shifts toward the representation of a future where the city empowers its own capacity for action, which is going to generate benefits for everybody. Based upon the construction of the chronological causal narrative, the framing implies that the perceived domination of the Navy over city development is to be transformed into an equal and negotiated relation for the common good.

The other main strategy is keeping "out of the public sphere" (Weaver, 1986: 385) the real degree of consensus - in fact, its weakness - in the relations between the city and the Navy.

\footnotetext{
${ }^{22}$ The "strategic square metre" is a motto used by all interviewed local officials in post when asked about the land issue. It has been used firstly by the Mayor and then regularly quoted by civil servants and deputy-mayors, and by the municipal newspaper.

${ }^{23}$ Interview with the Principal deputy-mayor.
} 
The way the military presence in Toulon is framed by local government has been poorly perceived by interviewed high-ranking commanding officers. But, they had less access to the public local arena for making their opinion heard than the local government. It is hard to argue that the Navy is a weak organisation with limited political and institutional resources. However, as far as local affairs are concerned, its ability to go public in the urban arena is bounded by the limited freedom of expression of marines (and of high-ranking civil servants in general) and by their belonging to a hierarchical organisation dependent on the political power in Paris. On the one hand, high-ranking marines who rule the Navy in Toulon cannot publicly oppose the Mayor, and on the other hand, elected officials do not have any interest in making public a conflict in which a relevant and complex constituency is implicated. As a consequence, there is no mention in either the main regional newspaper nor in the municipal magazine of conflicts between urban elites. In turn, the "perfect harmony" and the "industrious collaborations" between the city and the Navy are publicised on a regular basis in these same publications.

\section{b. Political strategies for policy implementation and the partial failure of the local partnership}

Along with policy framing, two main strategies have been undertaken by the municipality during recent years in order to advance the urban agenda. The preference of using one strategy as against the other depends on the power struggle and the degree of consensus relevant to the particular issue between the Navy and local government. The institutionalisation of bi-lateral meetings at the local level between the mayor and the Préfet Maritime (the highest military authority in Toulon) has been the main general strategy adopted by Mayor Hubert Falco to deal with every-day policy-making with the Navy. Indeed, the meetings were launched at the beginning of the 2000s to discuss with the Navy the new 
urban agenda, the content of policy documents and policies that demanded collaboration ${ }^{24}$.

Those meetings are based upon established procedures: periodicity, location, pre-defined agendas, and some of them have been given a recognisable name, "Les rencontres MairieMarine” ("City-Navy meetings"). It is a process of stabilising relations between civilian and military hierarchies. Indeed, through the stabilisation of norms, they become permanent and self-reproducing institutions which reduce uncertainty and enhance commitment, favouring collective action (Hall and Taylor 1997; Di Maggio and Powell 1997). Further, since 2002 , two retired Navy admirals have been charged to help local government offices for working on policies requiring collaboration with the Navy. Retired admirals are both policy brokers and experts in the policy process because they belong to both worlds (Hassenteufel 2008). They are former high-level commanding officers, with personal relationships with several stillserving officers and they are generally held in high respect by the military hierarchy. They thus have social resources that enable them to lead debates and to have their views taken into account. In addition, they have a deep knowledge of how a military institution functions. In the everyday making of local policies, they are the ones to be consulted concerning the organisation chart ("which is the right office to contact?"), the values and the norms of the military institution, and the best language to be used.

By contrast, for land disposal the Mayor used his political resources to deal directly with the central government and get around the local institutional veto. In a context of multilayered governance, the existence of a constraint in a specific level of government can lead an actor to displace the action to a level where power relations are more liable to be favourable and the request more readily taken into account (Kriesi, 2007). As pointed out earlier, Mayor Hubert

\footnotetext{
${ }^{24}$ The meetings take place both at the municipal and at the metropolitan level. The main issues are the policies for urban development related to R\&D project, the project for the quality of the bay waters (Section 3), issues related to urban planning (an agreement for the renewal of an ancient military tower, the tearing down of a wall that hid the sea but enclosed a military area, negotiations about the risk-perimeters surrounding the military base). At the very beginning, land disposal was also included in the topics, but later abandoned.
} 
625 Falco belonged to both the local and national level of government, and benefited from strong

626

627

628

629

630

631

632

633

634

635

636

637

638

639

640

641

642

643

644

645

646

647

648

649

support from the central government (Section 2). When he got his first national governmental charge in 2002, his double responsibility gave him direct access to the Minister of Defence,

Michèle Alliot-Marie. From that moment he mobilised his political resources in Paris in order to move around the blockages at the local level and to obtain satisfaction in some of his claims about the land through political negotiations. In 2004, conflicts about the land became acute in Toulon because of increasing pressures for land disposal, and civilian-military relations at the local level were interrupted for three years. The casus belli was the sports hall developed on a parcel of military land close to the naval base, and supposed to symbolise the "renouveau" of the city. The transfer of the land to the city was obtained thanks to political pressure on the MoD in Paris, and Navy officers in Toulon resented that the public equipment was built on what they consider to be "stolen land", and which the Navy still needed. Once the sports hall was built, an agreement regulated time-schedules between the inhabitants and defence employees and the maintenance responsibilities for the building; however, this ended in bitter conflict, with mutual accusations of reneging on these responsibilities. The episode showed the absence of locally constituted forums for conflict resolution about the land. It epitomised diverging interests and the absence of a stable bargaining context. Since then, the definition of what parcels of land can be given to the municipality (the non "strategic square meters") has been dealt with at the national level, following the classic French pattern where local interests are represented in Paris thanks to the holding of multiple posts at different levels of government (Goldsmith, Page, 1987). Furthermore, the negotiations about the waterfront failed to reach a conclusion, because national interest and the strategic relevance of Toulon were invoked in Paris to protect military activities in the bay. 


\section{Conclusion}

651

652

653

654

655

656

657

658

659

660

661

662

663

664

665

666

667

668

669

670

671

672

673

674

This article has used in-depth analysis of the evolution of relations between urban government, the Navy and a professional group (the marines) living in the city to understand both the transformation of urban policies and the way conflicts which arise are dealt with in a military city. The analysis has allowed the perception of the interplay between national and local levels, State policies and urban regulations.

It was demonstrated how changes in national policies (both defence and addressing urban and regional development), along with an increase of the political legitimacy and entrepreneurship of the mayor in Toulon, opened a window of opportunity for a new policy agenda of diversification requiring cooperation with the Navy. The Navy was perceived by elected officials as an exogenous power which made the area historically dependent on decisions taken at the national level. Since the 2000s, existing relations between the city and the Navy have been challenged. The Navy has been seen as one of the most relevant partners that needs to be involved in successful local development strategy, mostly because of its land ownership and technological skills and expertise. The analysis of the attempts to build up a policy coalition involving the Navy focused on the political and institutional techniques aimed at institutionalising civil-military relations. The establishment of routine meetings and hiring of retired admirals are complementary strategies that stabilise bargaining and reduce uncertainty. However, the most relevant common issue, land control, is dealt with by using political resources at the national government level. The Mayor, exploiting his double responsibilities (local and national), obtains satisfaction by direct recourse to the central government in Paris. The shift from the local to the national level and the interruptions in institutionalised meetings lead to the conclusion that the absence of regulation at the local level prohibits conflict solving. A second result concerns political variables in urban governance. It was argued that the particular strategies used to deal with conflicting interests 
need to take into account both the need for establishing cooperation and mobilising the Navy's resources, and also the wish to control and so preclude possible electoral sanctions from this military-related constituency. Indeed, the weight of the "military world" as a constituency favours strategies aimed at constructing losses and gains expected by the new policy agenda as a win-win situation, while managing conflicts behind closed doors. Here, this paper showed that broadening the analysis from organised interest and institutional context to electoral stakes and political competition allows a better understanding of the ways issues are framed and conflicting interests are managed.

Toulon has been conceptualised as a specialised military city, and the analysis was therefore constructed drawing on results shown in case-studies of other kinds of specialised cities (one-company towns, port-cities). On the one hand, the study of Toulon shows to what extent changes in a military city are close to what is recounted by the literature about specialised cities. On the other hand, it provides elements for understanding how exactly a military city can change in times of restructuring of defence policies and of the nation State. Urban policies in Toulon are similar to those in European cities where a particular activity was dominant. Indeed, new forms of partnership between the local government and the Navy, i.e. one the most relevant actor in the city, have developed in response to political and economic change. Because of political entrepreneurship of elected officials and of shrinking resources available to the dominant actor, the latter has become a partner in some local projects. However, Toulon is also a relevant case of a (partial) failure in urban governance, which suggests directions for further research. This case study of a military city shows how the emergence of flexible forms of coordination for collective action is not an automatic pattern of change in specialised European cities. In Toulon, the kind of actor involved is revealed to be crucial for the understanding of urban governance and its limits. Indeed, the Navy is a State institution whose priorities in national security make it an actor with concerns 
700 and interests which preclude it being fully involved in coalition for urban development.

701 Furthermore, resources available to the military administration enable it to maintain its 702 constraints upon the implementation of the new urban agenda. This case study therefore 703 qualifies how exactly partial urban governance emerged in the city. If governance is not linear 704 and it is often incomplete (Jessop 1993, Stoker, 2011), it is very pertinent for urban research 705 to test the set of conditions which foster or hamper this form of collective action. 
Agulhon, M. (2000) Histoire de Toulon. Privat.

708

709

710

711

712

713

714

715

716

717

718

719

720

721

722

723

724

725

726

727

Ardid, J.-C. (1995): Ils ont tue Yann Piat. Pleine Sud

Bagnasco, A. (1986) Torino. Un profilo sociologico. Einaudi Torino.

Bang, H. (2003) Governance as Social and Political Communication. Manchester University Press.

Béhar, D., and Estèbe, P. (1999) L'Etat peut-il avoir un projet pour le territoire? Les Annales de la Recherche Urbaine, (82), 80-91.

Bobbio, L. (2002) I governi locali nelle democrazie contemporanee. Laterza.

Borraz, O., and John, P. (2004) The Transformation of Urban Political Leadership in Western Europe. International Journal of Urban and Regional Research, 28(1), 107-120.

Breda-Vázquez, I., Conceição, P., and Fernandes, R. (2009) Partnership Diversity and Governance Culture: Evidence from Urban Regeneration Policies in Portugal. Urban Studies, 46(10), 2213 -2238.

Brenner, N. (2003) Metropolitan Institutional Reform and the Rescaling of State Space, Contemporary Western Europe, 10(4), 297-324.

Brenner, N. (2004) New State Spaces: Urban Governance and the Rescaling of Statehood. Oxford University Press, USA.

Chiamparino, S. (2002) Municipio, dialogo su Torino e il governo locale con Giuseppe Berta e Bruno Manghi. Venezia.

Davezies, L. (2008a) La République et ses territoires : La circulation invisible des richesses. Seuil, 2008. 
Davezies, L. (2008b) Etude de la base économique de la métropole toulonnaise. Agence d'Urbanisme de l'Aire Toulonnaise.

Denters, B., and Mossberger, K. (2006) Building Blocks for a Methodology for Comparative Urban Political Research. Urban Affairs Review, 41(4), 550-571.

Di Gaetano, A., and Strom, E. (2003) Comparative Urban Governance: An Integrated Approach. Urban Affairs Review, 38(3), 356-395.

Debrie, J., and Lavaud-Letilleul, V. (2009) La décentralisation des ports en France : de la recomposition institutionnelle aux mutations fonctionnelles. L'exemple de Toulon. Annales de géographie. 669(5), 498

Giersig, N. (2008) Multilevel urban governance and the "European City": discussing metropolitan reforms in Stockholm and Helsinki. VS Verlag.

Page, E. C.; Goldsmith, M. (1987): Central and Local Government Relations: A Comparative Analysis of West European Unitary States. SAGE Publications.

Haila, A. (1988) Four types of investment in land and property. Conference on Trends and Challenges of Urban Restructuring, Rio de Janeiro.

Harding, A. (1991) The rise of urban growth coalitions, UK-style? Environment and Planning C: Government and Policy, 9(3), $295-317$.

Harvey, D. (1985) The Urbanization of Capital: Studies in the History and Theory of Capitalist Urbanization. The Johns Hopkins University Press.

Hassenteufel, P. (2008) Sociologie politique : l'action publique. Armand Colin.

Haussermann, H., and Haila, A. (2004) The European City: A Conceptual Framework and A Normative Project. Cities of Europe. Changing contexts, local arrangements and the 

challenge to social cohesion. Blackwell Publishers.

751

752

753

754

755

756

757

758

759

760

761

762

763

764

765

766

767

768

769

770

Hébert, J-P. (1995) Production d'armement. Mutation du système français. La Documentation Française.

Hohenberg, P., Lees, L.-H. (1995) The Making of Urban Europe, 1000-1994. Harvard University Press.

Jessop, B. (1993) Towards a Schumpeterian Workfare State? Preliminary Remarks on PostFordist Political Economy. Studies in Political Economy, 40, 7-40.

John, P. (2001) Local Governance in Western Europe. SAGE Publications.

John, P., and Cole, A. (1999) Political leadership in the new urban governance: Britain and France compared. Local Government Studies, 25(4), 98.

Kazepov, Y. (2005) Cities of Europe: Changing Contexts, Local Arrangement and the Challenge to Urban Cohesion. Wiley-Blackwell.

Kazepov, Y. (2010) Rescaling Social Policies: Towards Multilevel Governance in Europe. Ashgate Publishing Limited.

Kilburn, H. W., (2004) Explaining U.S. Urban Regimes: A Qualitative Comparative Analysis. Urban Affairs Review. 39(5), p. 633-651.

Kriesi, H., Tresch, A., Jochum, M. (2007) Going Public in the European Union: Action Repertoires of Western European Collective Political Actors. Comparative Political Studies. 40(1), 48-73

Lagroye, J., Lehingue, P., Sawicki, F. (2004): Mobilisations électorales. Le cas des élections municipales de 2001. Presses Universitaires de France - PUF 
Lange, P., Regini, M. (1989) State, Market and Social Regulation: New Perspectives on Italy. Cambridge University Press.

Le Galès, P. (1995) Du gouvernement des villes à la gouvernance urbaine. Revue française de science politique, 45(1), 57-95.

Le Galès, P. (2003) Le retour des villes européennes. Les Presses de Sciences Po.

Logan, J.R. and Molotch, H.L. (1987) Urban Fortunes: The Political Economy of Place. University of California Press.

Lorrain, D (1991) De l'administration républicaine au gouvernement urbain. Sociologie du Travail 33(4), 461-484.

Martin, V. (1996): Toulon la noire : le Front national National au pouvoir.

North, D. C., and Weingast, B. R. (1989) Constitutions and Commitment: The Evolution of Institutional Governing Public Choice in Seventeenth-Century England. The Journal of Economic History, 49(4), 803-832.

Page, E. C., Goldsmith, M. (1987) Central and Local Government Relations: A Comparative Analysis of West European Unitary States. SAGE Publications.

Pierre, J. (2005) Comparative Urban Governance: Uncovering Complex Causalities. Urban Affairs Review, 40(4), 446-462.

Pinson, G. (2009) Gouverner la ville par projet : Urbanisme et gouvernance des villes européennes. Les Presses de Sciences Po.

Pizzorno, A. (1960) Comunità e razionalizzazione. Einaudi.

Prat, P. (2008) Le maire en action : gouvernement urbain et production de politiques 
793

794

795

796

797

798

799

800

801

802

803

804

805

806

807

808

809

810

811

812

813

Sellers, J. M. (2002) Governing from Below: Urban Regions and the Global Economy. Cambridge University Press.

Stoker, G., and Mossberger, K. (1994) Urban regime theory in comparative perspective. Environment and Planning, 12(2), $195-212$.

Stoker, G. (2011) Was local governance such a good idea? A global comparative perspective. Public Administration, 89(1), 15-31.

Stone, D. A. (1989) Causal Stories and the Formation of Policy Agendas. Political Science Quarterly, 104(2), 281-300.

Stockholm International Peace Research Institute (SIPRI) Military Expenditure Database for 2010.

Tsebelis, G. (2002) Veto Players: How Political Institutions Work. Princeton University Press.

Weaver, R. K. (1986) The Politics of Blame Avoidance. Journal of Public Policy, 6(04), 371398.

Zukin, S. (1991) Landscapes of Power: From Detroit to Disney World. University of California Press.

(Scott 2008)(Brenner et Theodore 2002) (Dormois 2008)(Kingdon 1984)

(Hall et Taylor 1997) (Di Maggio et Powell 1997)

(Haussermann et Haila 2004) 
Brenner, Neil, et Nik Theodore. 2002. «Cities and the Geographies of "Actually Existing Neoliberalism" ». Antipode 34 (3): 349-379.

Dormois, Rémi. 2008. «Les coalitions dans l'analyse des politiques urbaines postkeynésiennes. Discussion à partir de la comparaison des politiques de régénération urbaine menées dans trois villes européennes en reconversion ». Métropoles (4).

Hall, Peter A., et Rosemary C. R. Taylor. 1997. «La science politique et les trois néoinstitutionnalismes ». Revue française de science politique 47 (3): 469-496. doi:10.3406/rfsp.1997.395192.

Haussermann, Hartmut, et Anne Haila. 2004. « The European City: A Conceptual Framework and Normative Project ». In Cities of Europe. Changing contexts, local arrangements and the challenge to social cohesion, 43-63. Oxford: Blackwell Publishers.

Kingdon, John W. 1984. Agendas, Alternatives and Public Policies. TBS The Book Service Ltd.

Di Maggio, Paul J., et Walter W. Powell. 1997. «Le néo-institutionnalisme dans l'analyse des organisations ». Politix 10 (40): 113-154. doi:10.3406/polix.1997.1703.

Scott, Allen J. 2008. « Resurgent Metropolis: Economy, Society and Urbanization in an Interconnected World ». International Journal of Urban and Regional Research 32 (3) (septembre): 548-564. doi:10.1111/j.1468-2427.2008.00795.x.

Brenner, Neil, Nik Theodore. 2002. «Cities and the Geographies of "Actually Existing Neoliberalism" ». Antipode 34 (3): 349-379.

Dormois, R. 2008 “Les coalitions dans l'analyse des politiques urbaines post-keynésiennes. Discussion à partir de la comparaison des politiques de régénération urbaine menées dans trois villes européennes en reconversion" Métropoles (4).

Hall, P. A., Taylor, R. C. R. 1997. "La science politique et les trois néo-institutionnalismes". Revue française de science politique 47 (3): 469-496.

Haussermann, H. and Haila, A. 2004. «The European City: A Conceptual Framework and Normative Project ». In Cities of Europe. Changing contexts, local arrangements and the challenge to social cohesion, 43-63. Oxford: Blackwell Publishers.

Kingdon, J. W. 1984. Agendas, Alternatives and Public Policies. Boston: Little, Brown.

Di Maggio, P. J. and Powell W. W. 1997. “Le néo-institutionnalisme dans l'analyse des organisations. " Politix 10 (40): 113-154.

Scott, A. J. 2008. "Resurgent Metropolis: Economy, Society and Urbanization in an Interconnected World." International Journal of Urban and Regional Research 32 (3): $548-564$. 
Table I. Proportion of inhabitants of Toulon related to the Ministry of Defence*

\section{Number Percentage}

\section{Inhabitants}

Toulon inhabitants (2006)

167,816

Toulon inhabitants in work (2006)

70,764

Toulon inhabitants working for the MoD (2009)*

$11.7 \%$ of inhabitants in activity

who are career soldiers

5,807

$8.2 \%$ of inhabitants in activity

Retired inhabitants (2006)

38,870

People in receipt of a military pension (2010)

8,053

$20.7 \%$ of retired inhabitants

\section{Share of labour market}

Jobs in Toulon (2007)

75,931

MoD direct jobs (2009)**

17,177

$22.6 \%$ of total jobs

*Reliable data on families and children were not available

**Data on people working for the military procurement agency (DGA) were not available. The total number of those working for the MoD is therefore slightly under-estimated Sources: INSEE, Agence d'Urbanisme de l'Aire Toulonnaise (AUDAT), Ministry of Defence (Data collected and processed by the Author) 
857 Map I. Urban space under military control

858

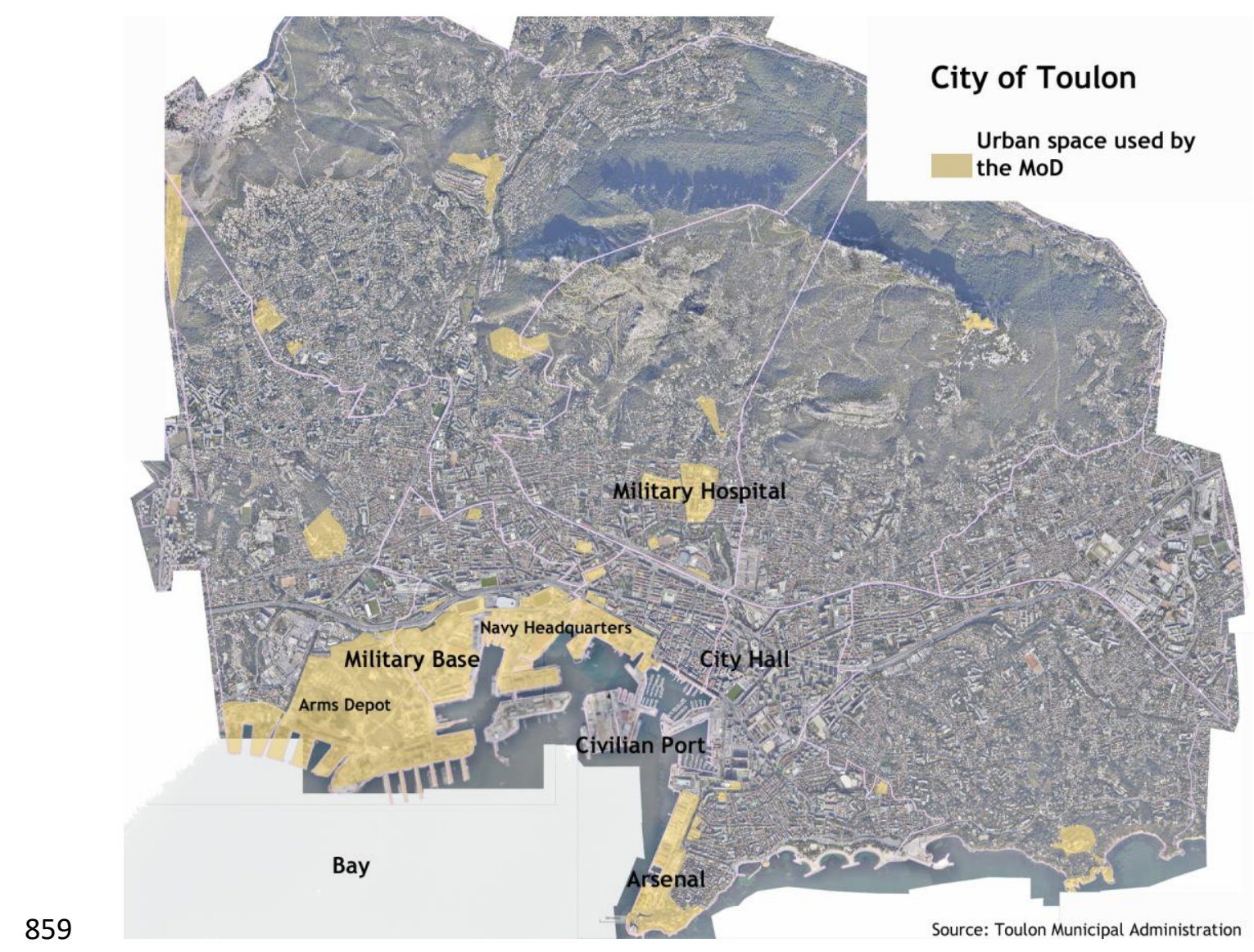

860

861 